\title{
Spillover effects of FDI on innovation in China: Evidence from the provincial data
}

\author{
Kui-yin CHEUNG, Ping LIN* \\ Department of Economics, Lingnan University, Tuen Mun, Hong Kong, China
}

Received 30 August 2002; accepted 13 June 2003

\begin{abstract}
Foreign direct investment (FDI) can benefit innovation activity in the host country via spillover channels such as reverse engineering, skilled labor turnovers, demonstration effects, and suppliercustomer relationships. Using provincial data from 1995 to 2000, we find positive effects of FDI on the number of domestic patent applications in China. This finding is robust under both pooled timeseries and cross-section data estimation and panel data analysis and for different types of patent applications (invention, utility model, and external design). The spillover effect is the strongest for minor innovation such as external design patent, highlighting a "demonstration effect" of FDI.
\end{abstract} (C) 2003 Elsevier Inc. All rights reserved.

JEL classification: $\mathrm{O} 31 ; \mathrm{O} 53$

Keywords: FDI; Spillover; Patent; Spatial effect

\section{Introduction}

One of the primary motivations for developing countries to attract foreign direct investment (FDI) is to obtain advanced technology from developed countries and then base on this to establish domestic innovation capability. Under its "market for technology" policy, China has been the largest recipient of FDI among the developing countries in the 1990s. Are there significant spillover effects from inward FDI on R\&D activity by the domestic firms? Or is it that China has been simply importing technologies without developing the ability to innovate on its own? This paper examines the extent to which inward FDI to China has affected innovation activities by Chinese firms.

* Corresponding author. Fax: +852-2891-7940.

E-mail addresses: kycheung@ln.edu.hk (K. Cheung), plin@ln.edu.hk (P. Lin). 
As is well recognized in the literature, there are several important channels through which inward FDI can benefit innovation activity of domestic firms in the host country. ${ }^{1}$ First, local firms can learn about the products and technologies brought in by foreign investors, by means of reverse engineering for example. Second, spillovers can take place through labor turnovers whereby local firms obtain the technological know-how of foreign-investment-related firms by "stealing" their skilled workers. Third, inward FDI has a demonstration effect on local R\&D activity. By their mere presence in the domestic markets, foreign products/technologies can inspire and stimulate local innovators to develop new products and processes. This helps shorten the trial-and-error process of local firms in their search for inventions. Moreover, since the products and technologies that FDI firms bring in have already been tested in foreign markets, the perceived risk of innovating along similar directions is lowered for local firms. Finally, spillovers may take place vertically from foreign firms to their local suppliers by means of technological know-how transfer, staff training, and so on. These vertical spillovers can then enhance the innovation capability of local suppliers. ${ }^{2}$

Our analysis is based on provincial-level data in China for the period from 1995 to 2000. We use the number of patent applications as a measure of R\&D output. To separate the spillover effect of FDI from the effects of other R\&D inputs, we include in our analysis the expenditures on science and technical development as well as the number of technical personnel. Other explanatory variables include export-output ratio of FDI firms and per capita GDP of each province.

We perform regression analyses for the pooled time-series and cross-section data as well as panel data estimations. We find evidence of positive spillovers from FDI (lagged 1 year) on the number of domestic patent applications under both approaches and for all three types of patents. The three types of patents are invention, which is a new technical solution relating to a product, process, or improvement thereof; utility model, which means a new technical solution relating to the shape or structure of a product that is not directly related to its aesthetic properties; and external design, which involves a new design of shape, pattern, or combination, or of color or aesthetic properties. This spillover effect is especially strong for external design patents: a $1 \%$ increase in FDI inflow can lead to a $0.15 \%$ increase in the number of applications for external design patent according to the panel data estimation, and a $0.47 \%$ increase according to the pooled data analysis. This finding is consistent with the demonstration effect of FDI, which is perhaps more applicable to external design innovation. We consider this finding to be a reflection of the current innovation capability of Chinese firms, which in general are technically lagged behind multinational firms, and thus the spillover effects of FDI are the strongest toward minor innovations.

Empirical studies of FDI spillover effects on innovation in China are rare. The only work that we are aware of is a recent study by Hu and Jefferson (2001). The authors used

1 There have been a number of recent studies of FDI spillovers to host countries. For example, Baldwin, Braconier, and Forslid (1999) studied R\&D spillovers through FDI for some OECD countries, while Aitken and Harrison (1999) examined the effect of FDI on productivity in Venezuela. See Blomstrom and Kokko (1999) for a review of empirical evidence of FDI spillover effects.

2 Several recent empirical studies have found that inward FDI leads to productivity improvement of local suppliers in some countries (see, e.g., Smarzynska, 2002). 
data for large- and medium-size enterprises to examine the spillover effects of FDI in manufacturing industries in China. ${ }^{3}$ They found that inward FDI has a positive effect on introduction of new products in China. Our study is complementary to Hu and Jefferson's in that we analyze the provincial data and emphasize the geographical aspect of FDI spillovers, whereas they focused on industry levels. Taken together, our findings and theirs show that FDI to China in the 1990s has promoted R\&D activity by Chinese firms via various spillover channels, making them more capable of innovating on their own. ${ }^{4}$

Our using provincial data is motivated by the fact that spatial proximity is of crucial importance for technology and knowledge spillovers, as documented in the literature on R\&D spillovers (e.g., Jaffe, 1986, 1989). It is well recognized that geographic proximity facilitates flow of knowledge. The probability that knowledge is transmitted from one agent to another decreases as geographic distance increases. The closer a local firm is located to an FDI firm, the more likely and more frequently their employees will interact with each other, and more frequent labor moves between these two firms. Moreover, the spatial aspect is also important for vertical spillovers between FDI firms and their local suppliers, which often are located close to one another. ${ }^{5}$

Our choice of the time period covered in our analysis, namely from 1995 to 2000, is based on two reasons. First, the patent law of China, although enacted in 1985, was substantially amended in 1993, with major revisions including extending patent length from 15 to 20 years for invention patents and from 5 to 10 years for patents on utility model and external design. In addition, the enforcement of the patent law has been greatly improved since then. Therefore, China's patent protection system in the post-1993 period is significantly different from the one prior to 1993. Second, it is since the 1990s that inward FDI to China has been consistently on a large scale. FDI to China before 1993 was on a relatively small scale and more fluctuating due to political changes in China such as the Tiananmen events in 1989 and the subsequent economic sanctions by major trading partners of China during early 1990s. The political uncertainty of investing in China was greatly reduced after Deng Xiaoping's South Tour in $1993 .^{6}$

Using the number of patent applications as a measure of R\&D output has several limitations. First, it is possible that some innovators in China may have chosen not to file patent applications for their R\&D output. Instead, they may have chosen to keep the fruits of their innovation activity as "trade secrets," so as to prevent their competitors from utilizing the information that would be disclosed from filing patent applications. Second, the number of patent applications does not reflect the quality of the inventions concerned. Alternatively, one could use other measures such as new product sales to account for the

\footnotetext{
3 Their data set, drawn from a private survey, spans a period of 5 years from 1995 to 1999 and 29 manufacturing industries and 511 firms.

4 In another recent article, $\mathrm{Hu}$ and Jefferson (2002) study the effects of FDI on total factor productivity of Chinese firms in electronic and textile industries. In Hu and Jefferson (this issue), the authors estimate the returns of R\&D investment in Chinese manufacturing industries.

5 For example, most of the component suppliers of Shanghai Santana are located in Shanghai or the surrounding area.

6 The FDI data we use are actually from 1994 to 1999 as we used lagged one period values of FDI in our regression analyses.
} 
value of $R \& D$ output. But one problem with using this alternative measure is that there may be a potentially large distortion in the official statistics about new products in China. This is so because enterprises in China tend to misreport information about new products to receive the tax credits the government provides to new products sales (as an incentive to stimulate R\&D). By (slightly) modifying their existing products, a firm can claim to have invented "new products" and thus enjoy the tax benefits. Because of this, it is likely that the official statistics about new product sales in China overestimate the commercial returns associated with introduction of genuine new products by Chinese firms. Another drawback of using new products sales to measure $R \& D$ output is that it does not include process innovations that improve the production technology for existing products. The number of patent applications includes both product and process innovations.

The rest of the paper is organized as follows. A theoretical framework of spillover effect of FDI on innovation is presented in section 2. Section 3 contains an overview of inward FDI to China during the second half of the 1990s and its distribution over the provinces. Section 4 contains a brief description of the patent protection system in China, as well as of patent application distributions across patent types and provinces. The regression model is contained in section 5. Main empirical findings are presented in section 6. Section 7 contains some estimation results regarding regional differences (Coastal, Central, and West regions) in FDI spillover effect. Section 8 provides some concluding remarks.

\section{Spillover effects of FDI on R\&D}

The R\&D process is essentially a knowledge generation process in which one utilizes resources (scientists, engineers, technicians, research equipment, and so on) to create new knowledge. In general, the R\&D production function can be represented by

$$
I=f\left(L, K, I_{0}\right),
$$

where $L$ and $K$ represent labor and the capital inputs and $I$ represents the R\&D output, which are largely embedded in the new products or new processes generated by the R\&D process. The component $I_{0}$ stands for the initial level of knowledge available at the beginning of the R\&D project concerned.

One of the important channels that contribute to the initial knowledge level is inward FDI. By bringing in new technologies and products into the host country, inward FDI can benefit domestic firms' innovation in several ways. First, local firms can learn about the designs of the new products and technology, through reverse engineering for example, and then improve upon them to come up with new innovations. The Japanese experiences in the 1960-1970s are a good example of this form of learning. Second, inward FDI can cause spillovers to local firms through labor market turnover whereby skilled workers who once worked for the FDI firms move to local firms. Quite a number of lawsuits against unfair competition in China in recent years are related to this type of labor mobility. ${ }^{7}$

\footnotetext{
7 See Chu (2001).
} 
Third, FDI can generate a "demonstration effect." The mere presence of foreign products in domestic markets can stimulate local firms' creative thinking and thus help generate blueprints for new products and processes. Moreover, since the products or technologies that FDI firms bring in have already been tested by consumers in the foreign markets, similar products and technologies will likely work well for the host country as well. ${ }^{8}$ Such a demonstration effect tends to be strong for minor innovations and significant in countries such as China where there was a lack of product variety prior to entry of foreign investors.

The demonstration effect is related to the usual R\&D spillovers in the literature of innovation, whereby information about a firm's on-going R\&D activity leaks to its competitors. Such information can benefit the competitors by improving their efficiency in the searching process for innovation. The FDI spillover effect, on the other hand, can be seen as originating from the FDI firm's finished R\&D projects (their products and technologies) and spillovers to local firms. By observing and analyzing the output of the FDI firm's past R\&D projects, local firms become more effective in conducting their own innovation activity. ${ }^{9}$

To focus on the effects of FDI on innovation, we can rewrite Eq. (1) as

$$
I=h(L, K, \mathrm{FDI}) .
$$

As argued in the Introduction, FDI spillovers can take place either horizontally or vertically. Horizontal spillovers occur when FDI firms' presence benefits their competitors in the same industry via channels such as reverse engineering, labor turnovers, formal or informal contacts between employees of FDI and local firms, and the demonstration effect. Vertical spillovers occur when FDI firms transfer technological know-how to their local suppliers through technology licensing and staff trainings. ${ }^{10}$ Both types of spillovers tend to be more effective when firms concerned are located closer to each other. This is so because geographic proximity facilitates flow of knowledge. More specifically, the main spillover channels such as labor turnover, informal meetings of employees of different firms, and supplier-customer contacts all function better among firms that are "clustered" spatially. Our use of provincial data helps to capture the spatial dimension of FDI spillover effects. ${ }^{11}$

Before presenting our empirical findings, we first provide a brief picture of inward FDI in terms of geographic distributions and the patent system in China.

8 If one considers innovation process as one in which desirable new products and processes are selected from an unknown set of alternatives, then the presence of foreign products tells local innovators that such specific candidates are in the feasibility set.

9 Of course, ongoing R\&D by the FDI firm can also spillover to local innovators. But most multinational companies that have entered the China market did not set up their own R\&D centers in China until recently.

${ }^{10}$ Such vertical spillovers are even stronger if local content requirement is imposed by the government, as was the case in China throughout the 1990s.

11 Furthermore, an important aspect of FDI to China is that investment by a foreign company often creates a number of smaller competitors (or imitators) in the sounding neighborhood of the FDI project. These new firms may be collectives or private owned enterprises. They may be either new or have been in other businesses prior to the entry of the FDI firm but losing money. The entry of the FDI firm creates profit opportunity for these new firms as they can mimic the products of the FDI firm. Through the various spillover channels, these new firms can improve on their innovation capability, and generate certain R\&D output over time. 


\section{FDI to China: 1995-2000}

In the early stage of China's opening up, FDI inflow increased at a modest rate until the early 1990s. The realized value of inward FDI to China was $\$ 3.49$ billion in 1990 , but soared to $\$ 27.5$ billion in 1993 . The figure reached $\$ 37.5$ billion in 1995 , peaked at $\$ 45.3$ billion in 1997 before declining to $\$ 40.3$ billion in 1999, largely due to the negative effects of the East Asia financial crisis. The volume of FDI inflow in 2000 was $\$ 40.7$ billion. The surge in FDI after 1993 was driven by several factors. Following Deng Xiaoping's support of further economic liberalization in 1993, the Chinese government resumed a policy of far reaching economic reforms and launched a new round of measures to attract FDI.

FDI to China is characterized by a very uneven geographic distribution. Regional breakdown of FDI shows a dividing line between coastal provinces and inland provinces in attracting foreign capital. As Table 1 shows, in 1996 nearly 90\% of FDI (in realized value) was concentrated in coastal provinces and more precisely in five of them: Guangdong, Jiangsu, Fujian, Shanghai municipality, and Shandong received more than $65 \%$ of total FDI. The Central region received only $9 \%$ and the West region only $2.45 \%$ of the total FDI inflow in that year. The geographic distributions of inward FDI in 1998 and 2000 (and in fact throughout the second half of the 1990s) were almost the same as it was in 1996. This uneven distribution is primarily due to the fact that the Coastal region is the most developed area in China and was the first region to allow FDI when China opened up in the 1980s.

\section{Patent protection in China}

In less than 20 years, China has made tremendous progress in establishing a legal system for the protection of innovation. China's first patent law was enacted in 1984 and came into effect in 1985. Since then, the law has been amended twice. The first revision, undertaken in 1992, extended the patent length from 15 to 20 years for invention patents and from 5 to 10 years for patents on utility model and external design. The second revision, which was completed in September 2000, eliminated the provisions under the old law that prevented state-owned enterprises from trading their patents in technology markets. The second revision also introduced new provisions designed to make it more rewarding for enterprise employees to innovate. Since the passage of the 1984 patent law, the central government has issued over 20 regulations and guidelines so as to promote innovation activity in China. Today's patent law in China is pretty much in line with the international standard. Up till now, China has acceded to all the international patent treaties and its laws on intellectual property rights meet the requirements of the WTO's Agreement on Trade-Related Intellectual Properties (TRIPs). Enforcement of the patent law has been greatly improved in China since the 1994 due to both the internal interests of China and external pressures from its major trading partners, such as the United States. $^{12}$

\footnotetext{
12 See Lin (2001) for a detailed description and evaluation of the patent system in China.
} 
Table 1

Spatial distribution of FDI inflow to China (\%)

\begin{tabular}{|c|c|c|c|}
\hline & 1996 & 1998 & 2000 \\
\hline \multicolumn{4}{|l|}{ Coastal region } \\
\hline Beijing & 3.71 & 4.79 & 4.17 \\
\hline Tianjin & 5.14 & 4.67 & 2.89 \\
\hline Hebei & 1.98 & 3.15 & 1.68 \\
\hline Liaoning & 4.15 & 5.31 & 5.07 \\
\hline Shanghai & 9.41 & 8.10 & 7.84 \\
\hline Jiangsu & 12.44 & 14.64 & 15.93 \\
\hline Zhejiang & 3.63 & 2.96 & 4.00 \\
\hline Fujian & 9.75 & 9.30 & 8.51 \\
\hline Shandong & 6.29 & 6.03 & 7.37 \\
\hline Guangdong & 28.07 & 28.78 & 27.97 \\
\hline Guangxi & 1.58 & 1.96 & 1.30 \\
\hline Hainan & 1.88 & 1.58 & 1.07 \\
\hline Subtotal & 88.04 & 91.28 & 87.80 \\
\hline \multicolumn{4}{|l|}{ Central region } \\
\hline Shanxi & 0.33 & 0.54 & 0.56 \\
\hline Inner Mongolia & 0.17 & 0.20 & 0.26 \\
\hline Jilin & 1.08 & 0.90 & 0.84 \\
\hline Heilongjiang & 1.35 & 1.16 & 0.75 \\
\hline Anhui & 1.21 & 0.61 & 0.79 \\
\hline Jiangxi & 0.72 & 1.03 & 0.56 \\
\hline Henan & 1.25 & 1.36 & 1.40 \\
\hline Hubei & 1.63 & 2.29 & 2.34 \\
\hline Hunan & 1.78 & 1.81 & 1.68 \\
\hline Subtotal & 9.52 & 9.90 & 9.17 \\
\hline \multicolumn{4}{|l|}{ West region } \\
\hline Chongqing & n.a. & 0.95 & 0.61 \\
\hline Sichuan & 1.05 & 0.82 & 1.08 \\
\hline Guizhou & 0.07 & 0.10 & 0.06 \\
\hline Yunnan & 0.16 & 0.32 & 0.32 \\
\hline Shaanxi & 0.78 & 0.66 & 0.72 \\
\hline Gansu & 0.21 & 0.09 & 0.15 \\
\hline Qinghai & 0.00 & n.a. & n.a. \\
\hline Ningxia & 0.01 & 0.04 & 0.04 \\
\hline Xinjiang & 0.15 & 0.05 & 0.05 \\
\hline Subtotal & 2.45 & 3.03 & 3.03 \\
\hline Total & 100 & 100 & 100 \\
\hline
\end{tabular}

China's Statistical Yearbook.

\subsection{Types of patents}

The patent law of China divides patents into three categories: invention, utility model, and external design. The term of protection is 20 years for invention patents and 10 years for utility model and external design patents. Invention patents are regarded as major innovations. To obtain a patent for invention, an application must meet the requirements of 
Table 2

Type of patent application

\begin{tabular}{lccr}
\hline & 1996 & 1998 & 2000 \\
\hline Domestic application & 82,207 & 96,233 & 140,339 \\
Invention (\%) & 13.95 & 14.26 & 18.06 \\
Utility model (\%) & 60.02 & 53.22 & 48.78 \\
External design (\%) & 26.03 & 32.51 & 33.16 \\
Overseas application & 20,528 & 25,756 & 30,343 \\
Invention (\%) & 83.04 & 86.33 & 87.01 \\
Utility model (\%) & 1.28 & 0.69 & 1.17 \\
External design (\%) & 15.18 & 12.99 & 11.82 \\
\hline
\end{tabular}

China's Statistical Yearbooks for Science and Technology.

"novelty, inventiveness, and practical applicability." Usually, it takes about 1 to $11 / 2$ years for the State Patent Office to process an invention patent application.

The applications for patents for utility model or design, on the other hand, need only to pass an initial examination wherein the patent office simply checks the completeness of files and makes sure the same object has not been patented before. The processing time for patent applications for utility model is about 6 months, and it is even shorter for design patent. $^{13}$

\subsection{Patent applications by domestic innovators}

Since 1995, the total number of patent applications filed annually from domestic inventors has increased significantly (see Table 2), rising from 68,880 in 1995 to 82,207 in 1996 and further to 140,339 in $2000 .^{14}$ In terms of patent type, the share of invention patent applications has been very low, holding at around just $14 \%$ during the period. The share of utility model patent applications, though declining, has been maintained at around $50 \%$. The number of patent applications for external design, however, has been growing in both absolute and relative terms, from about $22 \%$ in 1995 to $26.03 \%$ in 1996 and further to over $33 \%$ in 2000 . For comparison, the picture for overseas application is quite different, with over $87 \%$ of the applications being for major innovations (invention). Since our interest in on the effects on FDI on domestic innovation in China, we will refer to domestic patent applications for the rest of the paper.

There are several reasons that the proportion of domestic applications for invention patents has been low. First, relative to utility model and external design, successful

13 The information is obtained from a personal conversation with staff at the State Patent Office. Over the 1990s, patent application processing time has been declining, especially for invention patent, thanks to improved efficiency and increased manpower at the State Patent Office. In 1990, the processing time for the three types of patent applications was 26,6 , and 3 months, respectively.

14 Domestic applications include those applications filed by foreign invested enterprises (wholly foreign owned and joint venture) located in China, as well as those by Chinese firms. Typically, a foreign invested enterprise files protection for its intellectual property before it sets up a subsidiary or a joint venture in China, in which case the application is classified as overseas, rather than domestic. Moreover, once established, FDI firms in China typically do not conduct much $R \& D$, at least not on a large scale, for fear of leaking their R\&D information to local competitors. For this see China's Science and Technology Development Report 2000. 
discovery of inventions requires higher R\&D costs and a longer period of time. Second, in today's Chinese economy, the majority of firms are of small scale. Because of fastchanging market conditions, these small enterprises are more likely to focus their innovative effort on short-term R\&D projects, leading to a disproportionately large number of patents for utility model and design. Lastly, once invented, patents for utility model and design are easier to obtain, as they do not need to pass the test of "novelty, inventiveness, and practical applicability" set for invention patent. As a result, certain inventors may have chosen to file applications for utility model or external design patents, rather than for invention patent to have their new products enter the market quickly and at the same time to obtain legal protection as early as possible.

\subsection{Patent applications by provinces/regions}

Table 3 shows the distribution of different types of patent applications within the coastal, central, and west regions in China. Over time, we observe increases in the proportions of both invention and external design patents, accompanied by a declining proportion in utility model patents, in each of the three regions. The coastal provinces have the fastest growing but lowest shares of invention patent applications among the three regions, but the coastal provinces enjoy the largest shares in design patent applications. This can be attributed to the demonstration effect of FDI mentioned earlier. Specifically, since nearly $90 \%$ of the total FDI inflow has gone to the coastal region (Table 1), the demonstration effect should be the strongest in that region. Consequently, domestic innovators in the Coastal region have produced a higher proportion of external design patents, which are presumably easier to accomplish relative to invention and utility model patents by observing and imitating foreign products and technologies.

The distribution of patent applications across provinces/regions, as shown in Table 4, exhibits a large discrepancy between coastal provinces and inland provinces. In 1995, nearly $65 \%$ of patent applications (of all types) were filed by inventors from the coastal provinces and concentrated mainly in six of them: Guangdong, Beijing, Shandong, Liaoning, Jiangsu, and Zhejiang. These six provinces filed about $50 \%$ of total domestic patent applications in that year. The central region filed around $23 \%$ and the west region, only $12 \%$ of the total. This geographic distribution became even more uneven in 2000 , with about $18 \%$ and $10 \%$ in the central and west regions, respectively.

The distribution of patent applications across regions was even more uneven if we look at the types of application. In 1995, nearly $82 \%$ of design applications were filed from the

Table 3

Distribution of patent types within regions (\%)

\begin{tabular}{|c|c|c|c|c|c|c|c|c|c|}
\hline & \multicolumn{3}{|c|}{ Coastal region } & \multicolumn{3}{|c|}{ Central region } & \multicolumn{3}{|c|}{ West region } \\
\hline & 1996 & 1998 & 2000 & 1996 & 1998 & 2000 & 1996 & 1998 & 2000 \\
\hline Invention & 12.5 & 12.7 & 17.7 & 17.6 & 18.1 & 20.1 & 17.9 & 18.4 & 18.5 \\
\hline Utility model & 54.5 & 48.1 & 43.8 & 70.4 & 62.9 & 60.4 & 63.3 & 56.2 & 50.4 \\
\hline External design & 33.0 & 39.2 & 38.5 & 12.0 & 19.0 & 19.5 & 18.8 & 25.4 & 31.1 \\
\hline
\end{tabular}

China's Statistical Yearbook for Science and Technology. 
Table 4

Spatial distribution of domestic patent applications (\%)

\begin{tabular}{|c|c|c|c|c|c|c|c|c|}
\hline & \multicolumn{4}{|l|}{1995} & \multicolumn{4}{|l|}{2000} \\
\hline & All type & Invention & UM & Design & All type & Invention & UM & Design \\
\hline \multicolumn{9}{|l|}{ Coastal area } \\
\hline Beijing & 9.95 & 13.10 & 10.97 & 5.09 & 8.07 & 14.59 & 8.19 & 4.44 \\
\hline Tianjin & 2.58 & 2.50 & 2.89 & 1.78 & 2.18 & 2.01 & 2.45 & 1.88 \\
\hline Hebei & 4.23 & 4.46 & 5.02 & 1.91 & 3.00 & 2.57 & 3.99 & 1.86 \\
\hline Liaoning & 6.96 & 7.87 & 8.20 & 2.93 & 5.58 & 5.56 & 8.17 & 2.01 \\
\hline Shanghai & 3.84 & 3.66 & 3.81 & 4.06 & 8.85 & 20.17 & 4.53 & 8.79 \\
\hline Jiangsu & 6.38 & 5.63 & 6.79 & 5.73 & 6.41 & 4.96 & 7.54 & 5.60 \\
\hline Zhejiang & 6.32 & 3.74 & 5.82 & 9.40 & 8.05 & 3.68 & 7.29 & 11.42 \\
\hline Fujian & 3.10 & 2.09 & 2.05 & 6.64 & 3.29 & 1.61 & 2.49 & 5.28 \\
\hline Shandong & 7.23 & 6.72 & 7.31 & 7.36 & 7.82 & 5.33 & 9.42 & 6.93 \\
\hline Guangdong & 12.09 & 4.85 & 5.94 & 33.80 & 16.48 & 7.53 & 9.91 & 30.34 \\
\hline Guangxi & 1.93 & 2.27 & 1.85 & 1.90 & 1.37 & 1.08 & 1.74 & 1.03 \\
\hline Hainan & 0.29 & 0.34 & 0.17 & 0.57 & 0.39 & 0.43 & 0.20 & 0.63 \\
\hline Subtotal & 64.90 & 57.24 & 60.82 & 81.18 & 71.48 & 69.52 & 65.93 & 80.20 \\
\hline \multicolumn{9}{|l|}{ Central area } \\
\hline Shanxi & 1.43 & 1.82 & 1.71 & 0.43 & 1.15 & 1.45 & 1.41 & 0.63 \\
\hline In. Mongolia & 1.01 & 1.23 & 1.13 & 0.56 & 0.89 & 1.00 & 0.99 & 0.69 \\
\hline Jilin & 2.17 & 2.65 & 2.56 & 0.81 & 1.95 & 2.50 & 2.40 & 1.04 \\
\hline Heilongjiang & 4.02 & 4.81 & 4.75 & 1.50 & 2.42 & 2.85 & 3.32 & 0.96 \\
\hline Anhui & 1.61 & 1.59 & 1.84 & 0.97 & 1.46 & 1.29 & 1.77 & 1.13 \\
\hline Jiangxi & 1.58 & 1.93 & 1.78 & 0.79 & 1.21 & 1.14 & 1.32 & 1.10 \\
\hline Henan & 3.73 & 4.35 & 4.33 & 1.68 & 2.98 & 2.80 & 4.19 & 1.40 \\
\hline Hubei & 3.13 & 4.02 & 3.59 & 1.31 & 2.72 & 3.30 & 3.45 & 1.40 \\
\hline Hunan & 4.11 & 4.83 & 4.74 & 1.91 & 3.21 & 3.48 & 4.05 & 1.91 \\
\hline Subtotal & 22.80 & 27.21 & 26.41 & 9.96 & 18.01 & 19.82 & 22.91 & 10.25 \\
\hline \multicolumn{9}{|l|}{ West region } \\
\hline Chongqing & n.a. & n.a. & n.a. & n.a. & 1.39 & 0.99 & 1.53 & 1.41 \\
\hline Sichuan & 4.98 & 5.76 & 5.13 & 4.07 & 3.51 & 3.25 & 3.21 & 4.06 \\
\hline Guizhou & 0.88 & 1.39 & 0.83 & 0.66 & 0.77 & 0.74 & 0.83 & 0.71 \\
\hline Yunnan & 1.50 & 2.04 & 1.19 & 1.99 & 1.33 & 1.46 & 1.21 & 1.44 \\
\hline Shaanxi & 2.69 & 3.33 & 3.08 & 1.21 & 1.62 & 1.86 & 2.15 & 0.77 \\
\hline Gansu & 0.85 & 1.51 & 0.87 & 0.38 & 0.62 & 0.95 & 0.68 & 0.38 \\
\hline Qinghai & 0.16 & 0.24 & 0.17 & 0.06 & 0.14 & 0.15 & 0.15 & 0.11 \\
\hline Ningxia & 0.26 & 0.23 & 0.33 & 0.10 & 0.27 & 0.48 & 0.25 & 0.17 \\
\hline Xinjiang & 0.95 & 1.01 & 1.16 & 0.36 & 0.85 & 0.77 & 1.15 & 0.48 \\
\hline Subtotal & 12.28 & 15.55 & 12.77 & 8.86 & 10.50 & 10.64 & 11.15 & 9.55 \\
\hline
\end{tabular}

China's Statistical Yearbook for Science and Technology. Patent applications from Hong Kong, Macau and Taiwan are not included here.

coastal provinces. The four provinces, Guangdong, Zhejiang, Shandong, and Fujian, made up of more than $57 \%$ of total design applications. The central region filed only about $10 \%$ of total patent applications, and the west region made up of the rest. The high concentration in the geographic distribution (in the coastal region) has not changed much over the study period and is highly correlated with the inward FDI inflows, as can be seen by comparison with Table 1 . 


\section{The empirical model and data description}

Based on the theoretical model presented in section 2, we use the following model to estimate the spillover effects of FDI on innovation in China.

$$
\begin{aligned}
\text { Patent }_{i t}= & \beta_{0}+\beta_{1} \text { FDI }_{i t-1}+\beta_{2} \text { S\&Tper }_{i t}+\beta_{3} \text { S\&Texp }_{i t}+\beta_{4} \text { Fexport }_{i t} \\
& +\beta_{5} \text { PGDP }_{i t}+\varepsilon_{i t}
\end{aligned}
$$

where subscripts $i$ and $t$ denote province and time period, respectively. We use the number of patent application $\left(\right.$ Patent $_{i t}$ ) as a measure of R\&D output. $\mathrm{FDI}_{i t-l}$ refers to the realized value of FDI in province $i$ in year $t-1$. That is, FDI values lagged one period are used to analyze the spillover effect of FDI. Given that most of the patent applications filed in China are for minor innovations (utility model or external designs, Table 2), we believe it is reasonable to assume that FDI inflow to China impacts on domestic innovations within a short period of time. ${ }^{15}$ The coefficient $\beta_{1}$ measures magnitude of the spillover effect of FDI.

As measures of input to R\&D activity, we include the number of personnel for science and technical development (S\&Tper ${ }_{i t}$ ) and expenditures on science and technical development $\left(\mathrm{S} \& T e x p_{i t}\right)$, which are published by the State Bureau of Statistic every year. ${ }^{16} \mathrm{We}$ also include the share of foreign funded enterprises' export to its gross output (Fexport ${ }_{i t}$ ), so as to test whether FDI firms' exposure to international market might affect innovation activity of domestic firms in China. This export-output ratio also reflects to a large extent whether the presence of the FDI enterprises concerned is driven by cheaper labor motive or by the China's abundant domestic markets. Finally, to account for the fact that different provinces are at different stage of economic development so that their innovation capabilities should also differ, we include the level of per capita GDP $\left(\mathrm{PGDP}_{i t}\right)$ in our estimation.

The data are taken from China's Statistical Yearbooks and China's Statistical Yearbooks for Science and Technology, covering four administrative cities (Beijing, Tianjin, Shanghai, and Chongqing) and 26 provinces for the period from 1995 to 2000. Tibet is excluded in our analysis because most of the relevant data for it is either not available or zero during the time period examined. The sample thus consists of a total of 177 data points. (The Administrative City of Chongqing was established in 1997.) All variable values are transformed into logarithmic form.

Eq. (3) is estimated using the ordinary least squares (OLS) by pooling together the time-series and cross-section data. Panel data analysis is also conducted to account for regional heterogeneity across provinces. Under both the OLS and panel data approaches, Eq. (3) is estimated for each type of patent (invention, utility model, and design) as well as for all types of patent applications combined together. Among the five independent variables, we observe high correlation between science and technical development

\footnotetext{
15 In our regression analysis, we also used FDI lagged two periods, but either the coefficient is statistically insignificant or the residual sum of squares was larger than that for FDI lagged one period.

16 Data on R\&D personnel/expenditure, which are a part of S\&T personnel/expenditure, are not collected on a systematic basis under the current statistic system in China.
} 
personnel variable (S\&Tper) and science and technical development expenditure variable (S\&Texp). ${ }^{17}$ To reduce colinearity, we also estimate Eq. (3) using only one of these two variables at a time. Overall, estimations using all three combinations of independent variables produce qualitatively similar results.

\section{Empirical findings}

\subsection{Estimates of FDI effects from the pooled time-series and cross-section data}

Table 5 contains the OLS results obtained from pooled data estimations for the cases that only S\&T personnel is used as R\&D input and that both S\&T personnel and expenditure are used as input. The results when S\&T expenditure is used generates almost identical results in terms of FDI effect on patent application (indeed with slightly larger FDI coefficients). That case is not present here to save the space and to facilitate comparison with the panel data results.

As can be seen, the effects of FDI on patent applications are statistically significant and positive in all the cases in Table 5. The magnitudes of the FDI effects on patent applications are relatively large: a $1 \%$ increase in FDI can lead to a $0.12 \%$ increase in the number of applications for invention patents, a $0.18 \%$ increase for utility model patents, and around $0.47 \%$ increase for design patents. When patent applications of all types are combined together, the FDI coefficient is $0.27 \%$.

The ranking in the degree of FDI effects, namely that the effect is the strongest on design patent, followed by utility model and invention patents, is also reasonable because technically invention patents in general are the most sophisticated and design patents are the least sophisticated so that spillover effects are more likely on the design and utilitymodel patents than on the invention patents. The relatively large effect on design patent is also consistent with the "demonstration effect" of FDI mentioned earlier in that it is easier for domestic innovators to follow the examples of the external characteristics of foreign products or processes in creating their own new methods.

Before discussing the effects of other explanatory variables, we next present the findings from the panel data analysis regarding the spillover effects of FDI.

\subsection{Estimates of FDI effects from panel data analysis}

The panel data approach assumes that the intercept in Eq. (3) varies across provinces and thus can be written as $\beta_{0 i}$. Two alternative assumptions can be further made. The "fixed effect" model assumes that the intercept terms $\beta_{0 i}$ are fixed parameters. The "random effect" model, on the other hand, assumes that $\beta_{0 i}$ is random, so that they can be written as $\beta_{0 i}=\bar{\beta}_{0}+u_{i}$, where $u_{i}$ are independently identically distributed random variables with mean zero and constant variance. This error term $u_{i}$ can be viewed as province-

\footnotetext{
17 We believe this is largely due to the fact that S\&T expenses include labor costs of S\&T personnel as a major component. Other categories of S\&T expenditures include expenses on raw materials, fixed assets, etc.
} 
Table 5

Effects of FDI on domestic patent applications: pooled data estimations $(1995-2000, N=177)$

\begin{tabular}{lllllllll}
\hline & Invention & \multicolumn{3}{c}{ Utility model } & \multicolumn{2}{l}{ External design } & \multicolumn{2}{l}{ All patent } \\
\hline Constant & $-2.11^{* * *}$ & $-1.64 * * *$ & $-1.41^{* * *}$ & $-1.37 * * *$ & $-1.04 * *$ & -.30 & $-.85^{* * *}$ & -.48 \\
& $(-8.47)$ & $(-5.09)$ & $(-5.58)$ & $(-4.12)$ & $(-2.36)$ & $(-0.52)$ & $(-3.24)$ & $(-1.42)$ \\
FDI-1 & $.13 * * *$ & $.12^{* * *}$ & $.18^{* * *}$ & $.18^{* * *}$ & $.48^{* * *}$ & $.47 * *$ & $.27 * * *$ & $.27 * * *$ \\
& $(4.88)$ & $(4.54)$ & $(6.70)$ & $(6.57)$ & $(10.31)$ & $(9.97)$ & $(9.84)$ & $(9.13)$ \\
S\&Tper & $.70^{* * *}$ & $.56 * * *$ & $.77 * *$ & $.75 * * *$ & $.24 * * *$ & .02 & $.57 * * *$ & $.47 * * *$ \\
& $(18.48)$ & $(7.90)$ & $(19.91)$ & $(10.25)$ & $(3.52)$ & $(0.15)$ & $(14.49)$ & $(6.23)$ \\
S\&Texp & & $.15 * *$ & & .01 & & $.23 * *$ & & .11 \\
& & $(2.26)$ & & $(0.21)$ & & $(2.01)$ & & $(1.67)$ \\
Fexport & -.03 & -.02 & .04 & .04 & -.05 & -.04 & -.002 & .01 \\
& $(-0.54)$ & $(-0.38)$ & $(0.64)$ & $(0.65)$ & $(-0.53)$ & $(-0.39)$ & $(-0.03)$ & $(0.09)$ \\
PGDP & $.25 * * *$ & $.17 * *$ & .07 & .06 & $.34 * * *$ & $.22 *$ & $.17 * *$ & .11 \\
& $(3.81)$ & $(2.37)$ & $(0.99)$ & $(0.78)$ & $(2.99)$ & $(1.75)$ & $(2.52)$ & $(1.47)$ \\
Adj. $R^{2}$ & .85 & .86 & .88 & .88 & .76 & .76 & .87 & .87 \\
\hline
\end{tabular}

Dependent variable is the number of patent applications.

FDI-1 is FDI inflow lagged one year;

S\&Tper is number of science and technical personnel;

S\&Texp is amount of science and technical expenditure;

Fexport is the export-output ratio of FDI firms; and

PGDP is the per capita GDP.

All variables are in logarithm.

Figures in parentheses are $t$ statistics.

* Significant at the $10 \%$ level.

** Significant at the 5\% level.

$* * *$ Significant at the $1 \%$ level.

specific components which could represent the economic environments (such as the quality of infrastructure and/or the degree of intellectual property right law enforcement) of each province.

We conducted estimations using both the fixed effect and random effect models for each type of patent applications. The results are presented in Table 6. As in Table 5, we present the estimation results for two cases: (1) S\&T personnel as the only R\&D input, and (2) both S\&T personnel and S\&T expenditure as R\&D input. To shed light on the appropriateness of the fixed effect estimations versus the random effect estimations, we also conducted the Hausman tests with the corresponding $\chi^{2}$ and $P$ values as listed. The panel data results show significantly positive effects of FDI, except for utility model patent applications (in the fixed effect model).

Specifically, for invention patents we find positive spillover effects of FDI in both the fixed effect and the random effect models. This spillover effect is statistically significant according to the random effect estimations, but insignificant according to the fixed effect model. The corresponding $P$ values under the Hausman test .06 and .11 , respectively) suggest that the null hypothesis that the random effect model is the correct specification cannot be rejected at the $5 \%$ level. ${ }^{18}$ Thus, the effects of FDI on

\footnotetext{
18 See Judge, Hill, Griffiths, Lutkepohl, \& Lee, 1987, chap. 16. According to some scholars, however, "there is no simple rule" in selecting between the fixed effect and the random effect models, despite the Hausman test. See Johnson and DiNardo (1997, p. 403).
} 
Table 6

Panel data estimates of FDI effects on domestic patent applications (1995-2000): Fixed Effect (FE) vs. Random Effect (RE) models

\begin{tabular}{|c|c|c|c|c|c|c|c|c|c|c|c|c|c|c|c|c|}
\hline & \multicolumn{4}{|l|}{ Invention } & \multicolumn{4}{|c|}{ Utility model } & \multicolumn{4}{|c|}{ External design } & \multicolumn{4}{|c|}{ All patent } \\
\hline & $\mathrm{FE}$ & $\mathrm{RE}$ & $\mathrm{FE}$ & $\mathrm{RE}$ & $\mathrm{FE}$ & $\mathrm{RE}$ & $\mathrm{FE}$ & $\mathrm{RE}$ & $\mathrm{FE}$ & $\mathrm{RE}$ & $\mathrm{FE}$ & $\mathrm{RE}$ & $\mathrm{FE}$ & $\mathrm{RE}$ & $\mathrm{FE}$ & $\mathrm{RE}$ \\
\hline Constant & $\begin{array}{l}-1.98 * * * \\
(3.24)\end{array}$ & $\begin{array}{l}-2.27 * * * \\
(-7.06)\end{array}$ & $\begin{array}{l}-1.48 * * \\
(-2.36)\end{array}$ & $\begin{array}{l}-1.84 * * * \\
(-5.13)\end{array}$ & $\begin{array}{l}0.52 * \\
(1.71)\end{array}$ & $\begin{array}{l}-0.56^{* *} \\
(2.19)\end{array}$ & $\begin{array}{l}0.86^{* * *} \\
(2.85)\end{array}$ & $\begin{array}{l}-0.20 \\
(-0.76)\end{array}$ & $\begin{array}{l}-1.72 * * \\
(2.17)\end{array}$ & $\begin{array}{l}-2.54 * * * \\
(-4.94)\end{array}$ & $\begin{array}{l}-0.83 \\
(-1.05)\end{array}$ & $\begin{array}{l}-1.75^{* * *} \\
(-3.19)\end{array}$ & $\begin{array}{l}0.07 \\
(0.16)\end{array}$ & $\begin{array}{l}-1.01 * * * \\
(-3.36)\end{array}$ & $\begin{array}{l}0.59 \\
(1.38)\end{array}$ & $\begin{array}{l}-0.51 \\
(-1.61)\end{array}$ \\
\hline FDI-1 & $\begin{array}{l}0.08 \\
(1.51)\end{array}$ & $\begin{array}{l}0.08 * * \\
(2.38)\end{array}$ & $\begin{array}{l}0.08 \\
(1.48)\end{array}$ & $\begin{array}{l}0.07 * * \\
(2.24)\end{array}$ & $\begin{array}{l}0.01 \\
(0.47)\end{array}$ & $\begin{array}{l}0.09^{* * *} \\
(3.64)\end{array}$ & $\begin{array}{l}0.01 \\
(0.41)\end{array}$ & $\begin{array}{l}0.09 * * * \\
(3.50)\end{array}$ & $\begin{array}{l}0.15 * * \\
(2.07)\end{array}$ & $\begin{array}{l}0.27 * * * \\
(5.14)\end{array}$ & $\begin{array}{l}0.14 * * \\
(2.07)\end{array}$ & $\begin{array}{l}0.26^{* * * *} \\
(5.02)\end{array}$ & $\begin{array}{l}0.04 \\
(0.95)\end{array}$ & $\begin{array}{l}0.14 * * * \\
(4.75)\end{array}$ & $\begin{array}{l}0.03 \\
(0.90)\end{array}$ & $\begin{array}{l}0.14^{* * * *} \\
(4.56)\end{array}$ \\
\hline S\&Tper & $\begin{array}{l}0.57 * * * \\
(4.23)\end{array}$ & $\begin{array}{l}0.69 * * * \\
(11.09)\end{array}$ & $\begin{array}{l}0.43^{* * *} \\
(2.96)\end{array}$ & $\begin{array}{l}0.56 * * * \\
(7.07)\end{array}$ & $\begin{array}{l}0.36^{* * * *} \\
(5.41)\end{array}$ & $\begin{array}{l}0.59 * * * \\
(10.59)\end{array}$ & $\begin{array}{l}0.26^{* * * *} \\
(3.75)\end{array}$ & $\begin{array}{l}0.49 * * * \\
(7.96)\end{array}$ & $\begin{array}{l}0.05 \\
(0.27)\end{array}$ & $\begin{array}{l}0.27 * * \\
(2.53)\end{array}$ & $\begin{array}{l}-0.22 \\
(-1.18)\end{array}$ & $\begin{array}{l}0.03 \\
(0.25)\end{array}$ & $\begin{array}{l}0.34 * * * \\
(3.53)\end{array}$ & $\begin{array}{l}0.56^{* * * *} \\
(8.75)\end{array}$ & $\begin{array}{l}0.18^{*} \\
(1.84)\end{array}$ & $\begin{array}{l}0.41^{* * * *} \\
(5.68)\end{array}$ \\
\hline S\&Texp & & & $\begin{array}{l}0.13 * * * \\
(2.64)\end{array}$ & $\begin{array}{l}0.13^{* * *} \\
(2.66)\end{array}$ & & & $\begin{array}{l}0.09^{* * * *} \\
(3.81)\end{array}$ & $\begin{array}{l}0.09 * * * \\
(3.29)\end{array}$ & & & $\begin{array}{l}0.23 * * * \\
(3.71)\end{array}$ & $\begin{array}{l}0.23^{* * * *} \\
(3.57)\end{array}$ & & & $\begin{array}{l}0.14 * * * \\
(4.08)\end{array}$ & $\begin{array}{l}0.13^{* * * *} \\
(3.79)\end{array}$ \\
\hline Fexport & $\begin{array}{l}0.20^{* * * *} \\
(2.82)\end{array}$ & $\begin{array}{l}0.12 * \\
(1.95)\end{array}$ & $\begin{array}{l}0.20^{* *} \\
(2.90)\end{array}$ & $\begin{array}{l}0.12 * * \\
(2.08)\end{array}$ & $\begin{array}{l}0.05 \\
(1.53)\end{array}$ & $\begin{array}{l}0.08 * * \\
(2.14)\end{array}$ & $\begin{array}{l}0.05 \\
(1.63)\end{array}$ & $\begin{array}{l}0.08^{* *} \\
(2.21)\end{array}$ & $\begin{array}{l}0.17 * \\
(1.85)\end{array}$ & $\begin{array}{l}0.16^{*} \\
(1.91)\end{array}$ & $\begin{array}{l}0.17^{* *} \\
(1.96)\end{array}$ & $\begin{array}{l}0.17 * * \\
(2.05)\end{array}$ & $\begin{array}{l}0.09^{*} \\
(1.91)\end{array}$ & $\begin{array}{l}0.11 * * \\
(2.42)\end{array}$ & $\begin{array}{l}0.09 * * \\
(2.04)\end{array}$ & $\begin{array}{l}0.12^{* *} \\
(2.56)\end{array}$ \\
\hline PGDP & $\begin{array}{l}0.33 * * \\
(3.87)\end{array}$ & $\begin{array}{l}0.29 * * * \\
(4.01)\end{array}$ & $\begin{array}{l}0.27 * * * \\
(3.15)\end{array}$ & $\begin{array}{l}0.23 * * * \\
(3.02)\end{array}$ & $\begin{array}{l}0.18 * * * \\
(4.17)\end{array}$ & $\begin{array}{l}0.11 * * \\
(2.61)\end{array}$ & $\begin{array}{l}0.14 * * * \\
(3.25)\end{array}$ & $\begin{array}{l}0.08^{*} \\
(1.76)\end{array}$ & $\begin{array}{l}0.92 * * * \\
(8.27)\end{array}$ & $\begin{array}{l}0.77 * * * \\
(7.47)\end{array}$ & $\begin{array}{l}0.82 * * * \\
(7.41)\end{array}$ & $\begin{array}{l}0.67 * * * \\
(6.45)\end{array}$ & $\begin{array}{l}0.37 * * * \\
(6.06)\end{array}$ & $\begin{array}{l}0.29 * * * \\
(4.95)\end{array}$ & $\begin{array}{l}0.30 * * * \\
(5.14)\end{array}$ & $\begin{array}{l}0.23 * * * \\
(3.93)\end{array}$ \\
\hline$\chi^{2}$ & & 9.02 & & 8.89 & & 42.92 & & 61.12 & & 60.71 & & 106.53 & & 20.05 & & 22.20 \\
\hline Prob $(>0)$ & & 0.06 & & 0.11 & & 0.00 & & 0.00 & & 0.00 & & 0.00 & & 0.00 & & 0.00 \\
\hline
\end{tabular}

Dependent variable is the number of patent applications.

FDI-1 is FDI inflow lagged one year;

S\&Tper is number of science and technical personnel;

S\&Texp is amount of science and technical expenditure;

Fexport is the export-output ratio of FDI firms; and

PGDP is the per capita GDP.

All variables are in logarithm.

Figures in parentheses are $t$ statistics.

* Significant at the $10 \%$ level.

$* *$ Significant at the $5 \%$ level.

$* * *$ Significant at the $1 \%$ level. 
invention patent applications are statistically significant as shown by the random effect model. The magnitude of such effect (.08) is lower than found in the pooled data regressions (.13).

For utility model patents, the effect of FDI is almost zero and statistically insignificant according to the fixed effect estimations, whereas it is significantly positive in the random effect model. The Hausman test (high $\chi^{2}$ values) indicate that the fixed effect model is more appropriate. Consequently, unlike in the case of pooled data estimation, the panel date analysis does not yield evidence of FDI effects on patent applications for utility model patents.

Turning to patent application for external design, we find significantly positive effects of FDI in both the fixed effect and the random effect models, with the estimated coefficients being around .15 and .27 , respectively. Again, as in the case for utility model patent, the high values of $\chi^{2}$ obtained in the Hausman test (60.71 and 106.53) suggest that the null hypothesis of random effects is rejected. Thus, the effect of FDI in this case is .15 as the fixed effect model shows, much smaller than the pooled data estimation in Table 5 (about .47). As for all patent types combined together, the fixed effect model finds positive but insignificant effect of FDI, while the random effect model find significantly positive FDI effects but is rejected according to the Hausman test results.

In sum, similar to the findings from the pooled time-series and cross-section data analysis, the panel data estimations reveal significantly positive effects of FDI on innovation in China except for utility model patents in which case the effect of FDI is positive but insignificant (under the fixed-effect panel data estimation). In terms of the magnitude of FDI effect, the panel data estimations reveal smaller FDI coefficients relative to the pooled data approach. Therefore, without accounting for provincial heterogeneity, the pooled data estimations appear to overestimate the effects of FDI.

Overall, we interpret the two sets of findings from the pooled data and panel data analyses as being largely consistent with one another in that both reveal significant and positive spillover effects of FDI on domestic innovations, especially on design patent applications which account for over $30 \%$ of all domestic applications in China during the second half of 1990s. The strong effects of FDI on external design patent applications, as revealed under both the pooled data and panel data estimations, can be understood by noting that design patents are technically less sophisticated and that the demonstration effect of FDI is perhaps more applicable to such innovation, relative to invention and utility model patents.

\subsection{Effects of other variables: pooled data versus panel data estimates}

We now turn to the effects of other independent variables as contained in Table 5 for pooled date estimations and Table 6 for panel data analysis.

As expected, the effects of S\&T personnel and S\&T expenditures are positive and significant in almost all cases, ranging from .24 to .77 under the pooled data estimations and from .03 to .57 under the panel data estimations. Across patent types, the effects of S\&T input (e.g., S\&T personnel) are stronger for invention and utility model than for design patent. For example, from the pooled data analysis, the estimated coefficient of S\&T personnel is around .70 for invention and utility model patents, whereas it is only .24 
for external design patent. The panel data results reveal the similar pattern. ${ }^{19}$ Interestingly, as mentioned above, the effect of FDI is the strongest on design patent, relatively to invention and utility model patents. Lastly, for each type of patent considered, the effects of R\&D input variables are much stronger than the FDI spillover effect. Take the case of invention patent under panel data analysis for example, the FDI effect is about .08 whereas the effect of S\&T input is as big as .56. This ranking is natural because in general labor and capital input are the most important factors in R\&D activity and the effects of FDI are only indirect, albeit statistically significant in our study.

Turning to the export-output share of FDI firms (Fexport), we did not find significant effects on domestic innovation from the pooled data estimation but did so in the panel data analysis (at only the 10\% significance level). Theoretically, two hypotheses can be made regarding the potential effects of FDI firms' exposure to international markets on domestic R\&D. First, FDI firms with larger export-output shares are likely to be cheaper labor, rather than market oriented: These FDI firms come to China to utilize China's cheaper labor to produce products for international markets. Given this, the technologies they bring in are mostly labor intensive and consequently, the associated spillover effects on domestic innovation should be weak. Another hypothesis is that facing competitive forces in international markets these FDI firms would emphasize product quality and innovation. As a result, they should exhibit stronger spillover effects on domestic R\&D than otherwise. The spillover channels under both hypotheses may exist and cannot be ruled out a priori. Our finding here suggests that the opposing effects under the two hypotheses may cancel each other so that the net effect is weak.

Finally, for the effect of per capita GDP, we find significantly positive effects in all the cases in the panel data estimations, and for invention and design patents in the pooled data estimations. The estimated coefficients vary from .14 to .92. This indicates that the provinces that are better developed economically (such as those in the coastal area) tend to be more productive in $R \& D$ activity. This finding is not surprising because the level of human capital, infrastructure, and so on are in general positively correlated to the level of economic development. This reinforces the belief that the level of economic development is a major determinant of innovation activities across provinces in China.

\section{Spillover effects of FDI by regions (pooled data analysis)}

As is well known, there are substantial differences among the coastal, central, and the west regions in China in terms of the timing of allowing inward FDI, volume of FDI inflow, R\&D capability, and the level of economic development in general. One naturally expects that the spillover effect of FDI in China also exhibits regional differences. To examine the extent of such regional differences, we estimate Eq. (3) for each of the three regions using pooled data OLS method. Table 7 contains the results for the case that

\footnotetext{
19 In the panel data estimations, the effect of S\&T personnel on design patent is not significant as presented in Table 6 (fixed effect model). But if S\&T expenditure was used instead in the regression, it does have a positive and significant effect with the coefficient being .21 .
} 
Table 7

Effects of FDI on domestic patent applications across regions pooled data estimations (1995-2000)

\begin{tabular}{|c|c|c|c|c|c|c|c|c|c|c|c|c|}
\hline & \multicolumn{4}{|c|}{ Coastal region } & \multicolumn{4}{|c|}{ Central region } & \multicolumn{4}{|l|}{ West region } \\
\hline & Invention & $\begin{array}{l}\text { Utility } \\
\text { model }\end{array}$ & Design & $\begin{array}{l}\text { All } \\
\text { patent }\end{array}$ & Invention & $\begin{array}{l}\text { Utility } \\
\text { model }\end{array}$ & Design & $\begin{array}{l}\text { All } \\
\text { patent }\end{array}$ & Invention & $\begin{array}{l}\text { Utility } \\
\text { model }\end{array}$ & Design & $\begin{array}{l}\text { All } \\
\text { patent }\end{array}$ \\
\hline Constant & $\begin{array}{l}-4.44 * * * \\
(-4.81)\end{array}$ & $\begin{array}{c}-1.65^{*} \\
(-1.89)\end{array}$ & $\begin{array}{c}-2.72 * \\
(-1.79)\end{array}$ & $\begin{array}{l}-1.46 \\
(-1.37)\end{array}$ & $\begin{array}{l}-2.89 * * \\
(-2.16)\end{array}$ & $\begin{array}{c}-2.14^{*} \\
(-1.68)\end{array}$ & $\begin{array}{l}-0.30 \\
(-0.18)\end{array}$ & $\begin{array}{l}-1.07 \\
(-0.91)\end{array}$ & $\begin{array}{l}-3.66^{* * *} \\
(-2.32)\end{array}$ & $\begin{array}{l}-3.63 * * * \\
(-2.41)\end{array}$ & $\begin{array}{c}-6.14^{*} \\
(-1.70)\end{array}$ & $\begin{array}{c}-3.09^{*} \\
(-1.85)\end{array}$ \\
\hline FDI-1 & $\begin{array}{c}-0.07 \\
(-0.84)\end{array}$ & $\begin{array}{l}0.07 \\
(0.94)\end{array}$ & $\begin{array}{l}0.91 * * * \\
(6.74)\end{array}$ & $\begin{array}{l}0.37 * * * \\
(3.87)\end{array}$ & $\begin{array}{l}0.18^{* *} \\
(2.49)\end{array}$ & $\begin{array}{l}0.18 * * \\
(2.66)\end{array}$ & $\begin{array}{l}0.51 * * * \\
(5.60)\end{array}$ & $\begin{array}{l}0.23 * * * \\
(3.60)\end{array}$ & $\begin{array}{l}0.26 \text { *** } \\
(5.12)\end{array}$ & $\begin{array}{l}0.32 * * * \\
(6.73)\end{array}$ & $\begin{array}{l}0.48^{* * *} \\
(4.19)\end{array}$ & $\begin{array}{l}0.35 * * * \\
(6.47)\end{array}$ \\
\hline S\&Tper & $\begin{array}{l}0.77 * * * \\
(12.86)\end{array}$ & $\begin{array}{l}0.94 * * * \\
(16.65)\end{array}$ & $\begin{array}{l}0.24 * * \\
(2.44)\end{array}$ & $\begin{array}{l}0.67 * * * \\
(9.67)\end{array}$ & $\begin{array}{l}0.54 * * * \\
(3.79)\end{array}$ & $\begin{array}{l}0.73 * * * \\
(5.39)\end{array}$ & $\begin{array}{l}-0.14 \\
(-0.80)\end{array}$ & $\begin{array}{l}0.55^{* * *} \\
(4.44)\end{array}$ & $\begin{array}{l}0.47 \text { *** } \\
(5.51)\end{array}$ & $\begin{array}{l}0.42 * * * \\
(5.10)\end{array}$ & $\begin{array}{l}0.34 * \\
(1.72)\end{array}$ & $\begin{array}{l}0.40^{* * *} \\
(4.45)\end{array}$ \\
\hline Fexport & $\begin{array}{l}-0.31 \\
(-1.04)\end{array}$ & $\begin{array}{l}-0.09 \\
(-0.33)\end{array}$ & $\begin{array}{l}-0.73 \\
(-1.48)\end{array}$ & $\begin{array}{l}-0.38 \\
(-1.11)\end{array}$ & $\begin{array}{l}0.10 \\
(0.48)\end{array}$ & $\begin{array}{l}0.02 \\
(0.11)\end{array}$ & $\begin{array}{l}0.44 * \\
(1.70)\end{array}$ & $\begin{array}{l}0.10 \\
(0.56)\end{array}$ & $\begin{array}{l}0.08 \\
(0.46)\end{array}$ & $\begin{array}{l}0.12 \\
(0.68)\end{array}$ & $\begin{array}{l}-0.43 \\
(-1.02)\end{array}$ & $\begin{array}{l}-0.01 \\
(-0.05)\end{array}$ \\
\hline PGDP & $\begin{array}{l}0.33^{* * *} \\
(2.69)\end{array}$ & $\begin{array}{c}-0.20 * \\
(-1.70)\end{array}$ & $\begin{array}{l}0.13 \\
(0.65)\end{array}$ & $\begin{array}{l}0.00 \\
(-0.02)\end{array}$ & $\begin{array}{l}0.18^{*} \\
(1.98)\end{array}$ & $\begin{array}{l}0.00 \\
(0.03)\end{array}$ & $\begin{array}{l}0.48^{* * * *} \\
(4.13)\end{array}$ & $\begin{array}{l}0.12 \\
(1.42)\end{array}$ & $\begin{array}{l}0.31 \\
(2.07)\end{array}$ & $\begin{array}{l}0.48^{* * *} \\
(3.33)\end{array}$ & $\begin{array}{l}0.73^{* *} \\
(2.12)\end{array}$ & $\begin{array}{l}0.50 * * * \\
(3.12)\end{array}$ \\
\hline Adj. $R^{2}$ & 0.79 & 0.84 & 0.58 & 0.74 & 0.65 & 0.73 & 0.65 & 0.74 & 0.89 & 0.91 & 0.71 & 0.90 \\
\hline$N$ & 72 & & & & 54 & & & & 51 & & & \\
\hline
\end{tabular}

Dependent variable is the number of patent applications.

FDI-1 is FDI inflow lagged one year;

S\&Tper is number of science and technical personnel;

S\&Texp is amount of science and technical expenditure;

Fexport is the export-output ratio of FDI firms; and

PGDP is the per capita GDP.

All variables are in logarithm.

Figures in parentheses are $t$ statistics.

* Significant at the $10 \%$ level.

$* *$ Significant at the $5 \%$ level.

$* * *$ Significant at the $1 \%$ level. 
includes the $\mathrm{S} \& \mathrm{~T}$ personnel as the only $\mathrm{R} \& \mathrm{D}$ input variable. (The results when $\mathrm{S} \& \mathrm{~T}$ expenditure is included are similar.)

We find that the effects of FDI on patent applications are positive and significant in all three regions, and particularly so in the central and west regions where the FDI effects are significant and positive for all three types of patent. In the coastal provinces, however, only the effect on design patent is statistically significant and unusually large $(0.91 \%)$. The pattern that the west region has the strongest FDI spillover effect can be understood as follows. Although inward FDI to China has been concentrated in the coastal region (over $86 \%$ of the total FDI inflow), FDI into the west region is more concentrated within the region, relative to the coastal and the central regions. This can been seen from Table 1 which shows that during the second half of the 1990 s over $60 \%$ of the total FDI inflow to the west region went to the Sichuan (Chongqing City included) and Shaanxi, whereas the foreign investments to the east and central region were more evenly distributed among the provinces within the regions. Since location proximity is of crucial importance to technology/knowledge spillovers as emphasized in Introduction, higher degree of spatial concentration of FDI tends to yield a stronger spillover effect.

Second, the finding that the FDI coefficient on design patents in the coastal region is very large is related to the fact that design patent applications in China have concentrated mostly in the coastal region during the period studied. Over $80 \%$ of the design patent applications filed nationally during the second half of 1990s were from the coastal region (Table 4). Moreover, of the total number of patent applications filed within the coastal region nearly $40 \%$ are for external design patents (Table 3), the highest among the three regions. These facts help us understand why the spillovers of FDI on design patents are the strongest in the coastal area.

The estimated coefficients of S\&T personnel in all the regions are as expected. Similar to the case for the entire country under pooled data estimations (Table 5), the exportoutput ratio of FDI firms has no significant effect on domestic innovation (with the exception of design patent in the central region). The level of per capita GDP has significant impacts on all types of patent applications in the west, while having particularly strong effects on invention patent in coastal area and on external design patent in the central region.

\section{Concluding remarks}

It is well recognized that inward FDI can have beneficial effects to innovation activity in the host country via various spillover channels such as reverse engineering, labor mobility, demonstration effects, supplier-customer relationships, and so on. However, attempts to find empirical evidence of spillover effects of FDI in China are rare. This is surprising given that China has been the largest recipient of FDI among the developing countries in the 1990s and that it has been China's primary objective in the past two decades to develop its domestic innovative capacity by bringing in foreign investment and technology. Our work is among the first attempts to test empirically the spillover effects of FDI on innovation in China. 
In light of the importance of location proximity for knowledge spillovers, we use the data of 26 provinces (Tibet excluded) and 4 administrative cities (Beijing, Shanghai, Tianjing, and Chongqing) for the period of 1995-2000. We found evidence of positive spillover effects of FDI on the number of domestic patent applications. The spillover effect of FDI is the strongest on minor innovations (particularly external design patents). These findings are robust under both the OLS and panel data estimations. Relative to the coastal and central regions, the spillover effects of FDI are stronger in the west region where FDI inflow is spatially more concentrated.

We also find that science and technical personnel and expenditure are the most major determinants of innovation output, as it should be the case. In addition, they impact more strongly on major innovations (invention) than on minor innovations (utility model and design). The level of economic development (as measured by per capita GDP) also has strong impacts on R\&D activity in each province; provinces that are more developed such as those in the coastal region are more productive in generating patent applications. Furthermore, exports by the FDI firms in China to international markets appear to have marginally significant and positive effects on domestic patent applications.

As a first attempt to study spatial dimension of FDI spillover effects on innovation in China, we used provincial data in our analysis. Given the large sizes of provinces in China, a more satisfactory approach is to use observations from smaller spatial units like counties. If county-level data on FDI and innovation in China are available, future research along this line should reveal much detailed information about the spillover effects FDI in China. Using the number of patent applications to measure R\&D output also has some limitations as mentioned in the Introduction.

Finally, we would like to relate our results to the so-called crowing-out effect of FDI on innovation mentioned in the literature (e.g., see Lin, 2002). According to the crowding-out hypothesis, inward FDI might have a negative effect on domestic R\&D activity, because purchasing technologies from abroad (e.g., by setting up joint ventures with foreign investors) is a substitute for innovating on one's own. This substitute is more attractive when conducting one's own R\&D is risky, or when the technology concerned is of high standard (such as invention). However, we should note that even when a firm purchases foreign technology, such importing of FDI could still generate spillover effects afterwards to other local firms. Thus, it is likely that both the crowdingout effect and the spillover effects exit in practice. We did not find evidence of a crowding-out effect of FDI in that the estimated coefficients of FDI on patent applications are all positive. This suggests that either the crowding out effect is absent in China or it exists but is dominated by the positive spillover effects of FDI at the provincial level.

\section{Acknowledgements}

We thank an anonymous referee and the participants of the Greater China and the WTO Conference at the City University of Hong Kong, June 16-18, 2002, for their comments and suggestions. 


\section{References}

Aitken, B. J., \& Harrison, A. (1999). Do domestic firms benefit from direct foreign investment? Evidence from Venezuela. American Economic Review, 89, 605-618.

Baldwin, R., Braconier, H., \& Forslid, R. (1999). MNCs, growth and location externalities, CEPR working paper.

Blomstrom, M., \& Kokko, A. (1998). Multinational corporations and spillovers. Journal of Economic Surveys, $12(3), 247-278$.

Chu, M. C. (2001). Selected litigation cases of anti-unfair competition disputes. (in Chinese). Shanghai: Sanlian Press.

Hu, A., \& Jefferson, G. (2001). FDI, technological innovation, and spillover: Evidence from large and medium size Chinese enterprises, mimeo. Brandeis University: Waltham, MA.

Hu, A., \& Jefferson, G. (2002). FDI impact of spillover: Evidence from China's electronic and textile industries. World Economy, 25(8), $1063-1076$.

$\mathrm{Hu}, \mathrm{A} .$, \& Jefferson, G. (this issue). Returns to research and development in Chinese industry: Evidence from state-owned enterprises in Beijing. China Economic Review.

Jaffe, A. (1986). Technological opportunity and spillovers of R\&D: Evidence from firms' patents, profits and market value. American Economic Review, 76(5), 984-1001.

Jaffe, A. (1989). Characterizing the 'technological position' of firms, with application to quantifying technological opportunity and research spillovers. Research Policy, 18(2), 97.

Johnson, J., \& DiNardo, J. (1997). Econometric methods (4th ed.). New York: McGraw-Hill.

Judge, G., Hill, C., Griffiths, W., Lutkepohl, H., \& Lee, T. C. (1987). Introduction to the theory and practice of econometrics. New York: Wiley.

Lin, P. (2001). Protection of intellectual property rights in China. In Y. Y. Kueh, \& W. M. Zheng (Eds.), Globalization and Sino-US economic and trade relationship (pp. 372-397). Beijing: Social Science Press.

Lin, P. (2002). $R \& D$ in China and the implications for industrial restructuring, working paper no. 128. Center for Public Policy Studies, Lingnan University.

Smarzynska, B. K. (2002). Spillovers of foreign direct investment through backward linkages: Does technological gap matter? The World Bank working paper. 